\title{
Trend Analyses of Parameters of Equations for Maximum Fairness Proportion Achievable in Ubicomp MANETs Using Location-Aware Transmission.
}

\author{
M. Kaleem GALAMALI, Assoc. Prof Nawaz MOHAMUDALLY
}

\begin{abstract}
Research concerning control of energy consumption in ubicomp is deeply ongoing and MANET transmission is also forebode in assisting in this strategy [75]. The fact remains that this field is not yet fully established and hence notions of modelling in ubicomp are still poorly existent. Control on energy expenditure in ubicomp is essential due to present hardware level of constrained battery power. A prior study was undertaken [24] to quantify and model the Maximum Fairness Proportion (Max_FP) achievable for CBRs for node densities of 7 until 56. The corresponding model was described as combining linear and exponential trends.
\end{abstract}

In this paper, the successive level of probing is laid as: "What are the trends of variation observable within each parameter of the equations of curves obtained for metric Max_FP [24] over varying node densities?"

It is recommended that the behaviour of each component of suitable models for metric Max_FP be understood in form of mathematical equations before embarking seriously on predictability features. This endeavour will be tough since it will consume lots of effort and involve disagreements between researchers. The outcome generated in this paper will assist ubicomp researchers in more fruitful understanding of MANET features and develop algorithmic support for proper energy management in ubicomp architectures. It may eventuate significantly different battery design and surrogate devices needed. This paper is a follow-up of previous work [1-39].

Key terms: Ubicomp- Ubiquitous Computing, MAUCMobile and Ubiquitous Computing, MANET- Mobile Adhoc Network, CBR- Constant Bit Rate, Max_FPMaximum Fairness Proportion.

M. Kaleem GALAMALI,

University of Technology Mauritius (student) Mauritius

Assoc. Prof Nawaz Mohamudally

University of Technology Mauritius, Mauritius

\section{Introduction}

The amount of resources installed in ubicomp environments may be quite sparse and this can vary from one environment to another. In such situations, MANET transmission strategies are venerated as the befitting solutions. In MANETs, due to transmission load division, the criteria of Fairness must be well delimited. Among the different angles of studying Fairness, the study of existing metrics and development of new metrics remain promising. One such endeavour was made [24], whereby the patterns of metric Max_FP were illustrated as split into two:

- Previous to a peak value, the linear tendency is observed of form:

$$
F(x)=d * x+f
$$

- From the peak value onwards, the decreasing exponential trend is observed of form:

$\mathrm{G}(\mathrm{x})=\mathrm{a} * \exp (\mathrm{b} *(\mathrm{x}-\mathrm{k}))+\mathrm{c}$

Here, the equations of the model have implicated 6 parameters: a, b, c, d, f and k. The next study called for metric Max_FP is the formulation of model equations for the parameters of the equation mentioned above.

The key contributions of this paper is the development of the trend of variation for each parameter of the equations involved in the model for metric Max_FP presented in a prior study [24], from which Tables 1(a) and $1(b)$ are re-utilised here.

The mathematical procedures expounded here may be programmed into software simulators, thus entailing a utility for designers to more assiduously study the progression and predictability of ubicomp features and hence more accurately provision for future ubicomp architecture. The rest of this paper is organised as follows: section 2- Parameter Trend Analysis- Metric Max_FP, section 3- Conclusion and References.

\section{Parameter Trend Analysis - Metric Min_FP. \\ 2.0 General Procedure Adopted.}

The tabulated data for each parameter of the equations for the model for Max_FP is plotted on gnuplot. Then the procedure for undertaking graphical analyses and reporting general observations is undertaken. The successive step is to investigate the applicability of certain hypothetical equations of fit. Criterion for best fit has been value of least reduced chi-square for all parameters. For parameters $\mathrm{c}$ and d, additional criterion 
Proc. of the Seventh International Conference On Advances in Computing, Electronics and Electrical Technology - CEET 2017. Copyright (C) Institute of Research Engineers and Doctors. All rights reserved.

ISBN: 978-1-63248-126-9 doi: 10.15224/ 978-1-63248-126-9-13

of best extendability at node number 100 is applied. The values of parameters for each max_FP parameter of equation is jotted down.

\subsection{Trend Analysis - Max_FP parameter " $a$ ”.}

Generally the curve depicts a decreasing tendency at a decreasing rate. The curve however does not yet show asymptotic flattening.

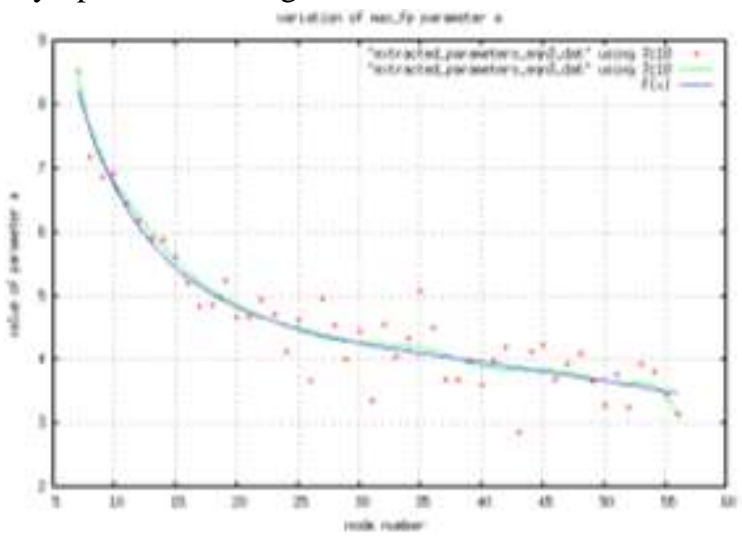

Figure 1: Max_FP parameter a

The potentially applicable equations are:

$$
\begin{aligned}
& \text { 1. } F(x)=(a \star \exp ((b \star x)+c))+d \\
& \text { Ch_sq }=0.164722 \\
& \text { 2. } F(x)=(a * x) /(\exp ((b \star x)+c))+d) \\
& \text { Ch_sq }=0.152416 \\
& \text { 3. } F(x)=((a * x)+f) /(\exp ((b * x)+c))+d) \\
& \text { Ch_sq }=0.152071 \\
& \text { 4. F } \left.(x)=\left(\left(a * x^{2}\right)+f\right) /(\exp ((b * x)+c))+d\right) \\
& \text { Ch_sq }=0.150301
\end{aligned}
$$

\section{Choice of best fit for Max_FP parameter a}

The equation in part 4 above has been selected because of both smallest reduced chi-square value obtained. The parameters for best fit are:

$\mathrm{a}=0.0037452, \mathrm{~b}=0.0351439, \mathrm{c}=-0.460414, \mathrm{~d}=$ $-0.530751, \mathrm{f}=2.0891$

\subsection{Trend Analysis - Max FP parameter " $b$ ",}

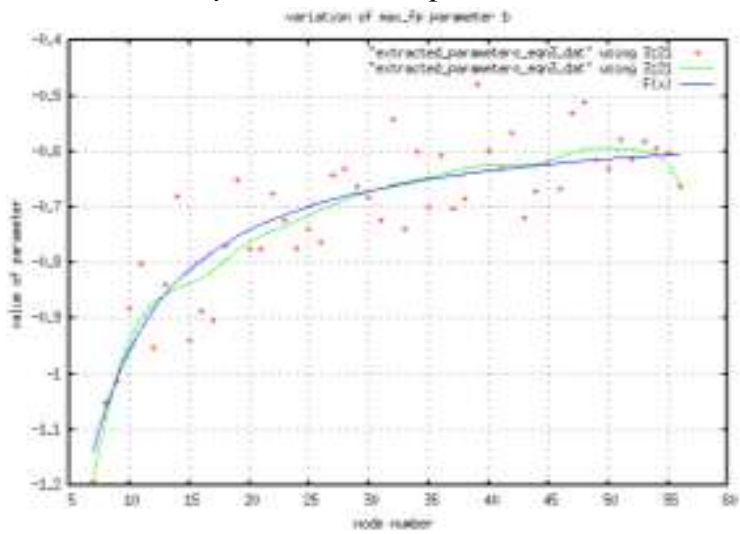

Figure 2: Max_FP parameter b

Generally, the curve depicts an increasing an increasing trend at a decreasing rate. No significant oscillation is found here. The potentially applicable equations of trend are:

$$
\begin{aligned}
& \text { 1. } F(x)=a * \exp (b * x)+c \\
& \text { Ch_sq }=0.00506435 \\
& \text { 2. } F(x)=(a / x) * \exp (b *(x+c))+d \\
& \text { Ch_sq }=0.00493007
\end{aligned}
$$

\section{Choice of best fit for Max_P parameter $b$}

The equation in part 2 above has been selected because it has smallest ch_sq value. Parameters for best fit are:

$\mathrm{a}=-4.28616, \mathrm{~b}=-0.00220667, \mathrm{c}=0.0118053, \mathrm{~d}=$ $-0.536591$

\subsection{Trend Analysis - Max FP parameter " $c$ ".}

The plots are very scattered. However the smooth bezier plot depicts a linear trend of very small gradient.

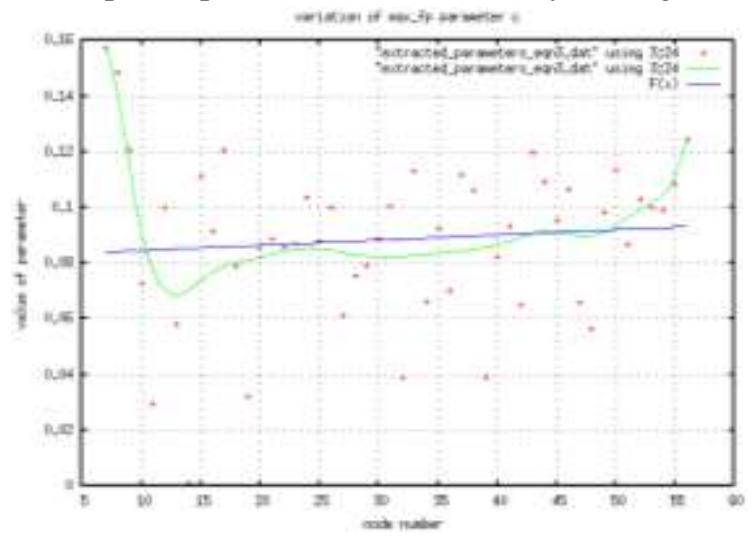

Figure 3: Max_FP parameter c

The potentially applicable equations of trend are:

$$
\begin{aligned}
& \text { 1. } F(x)=d \star x^{2}+f \star x+g \\
& \text { Ch_sq }=0.000 \\
& \text { Projection for } F(100) \text { is not good! } \\
& \text { 2. } F(x)=d \star x^{2}+f \\
& \text { Ch_sq }=0.000856657 \\
& \text { Projection for } F(100) \text { is better than part } 1 \text { above. } \\
& \text { 3. } F(x)=d \star x+f \\
& \text { Ch_sq }=0.000 \\
& \text { Projection for } F(100) \text { and beyond is much more stable. }
\end{aligned}
$$

\section{Choice of best fit for Max_P parameter c}

The equation in part 3 above has been selected because it has best extendability even if its ch_sq value is not least. The parameters for best fit are:

$d=0.000187397, f=0.0826164$

\subsection{Trend Analysis - Max_FP parameter " $d$ ".}

Generally the curve depicts a decreasing tendency at a decreasing rate. This is characteristic of inverse logarithmic behaviour. The plot at node number 7 appears as an outlier. 
Proc. of the Seventh International Conference On Advances in Computing, Electronics and Electrical Technology - CEET 2017. Copyright (C) Institute of Research Engineers and Doctors. All rights reserved.

ISBN: 978-1-63248-126-9 doi: 10.15224/ 978-1-63248-126-9-13



Figure 4: Max_FP parameter d

The potentially applicable equations of trend are:

$$
\begin{aligned}
1 . F(x) & =a /(\log (b * x)+C) \\
\text { Ch_sq } & =3.50363
\end{aligned}
$$

Expands well to $\mathrm{F}(100)$.

$$
\begin{aligned}
& \text { 2. } F(x)=(a / x) \star(\log (b * x)+c) \\
& \text { Ch_sq }=4.26256 \\
& \text { 3. } F(x)=\left(a * x^{-0.5}\right) /(\log (b * x)+c) \\
& \text { Ch_sq }=3.41229 \\
& \text { Expands well to } F(100)=1.812741194673 .
\end{aligned}
$$

\section{Choice of best fit for Max_P parameter d}

The equation in part 3 above has been selected because of least ch_sq and good extendability. The parameters for best fit are: $\quad \mathrm{a}=3.41229, \mathrm{~b}=8.23913, \mathrm{c}=$ 0.0453179

\subsection{Trend Analysis - Max_FP parameter "f".}

Generally the curve depicts a small increasing tendency at a slowly decreasing rate. The plot at node number 7 appears as an outlier.

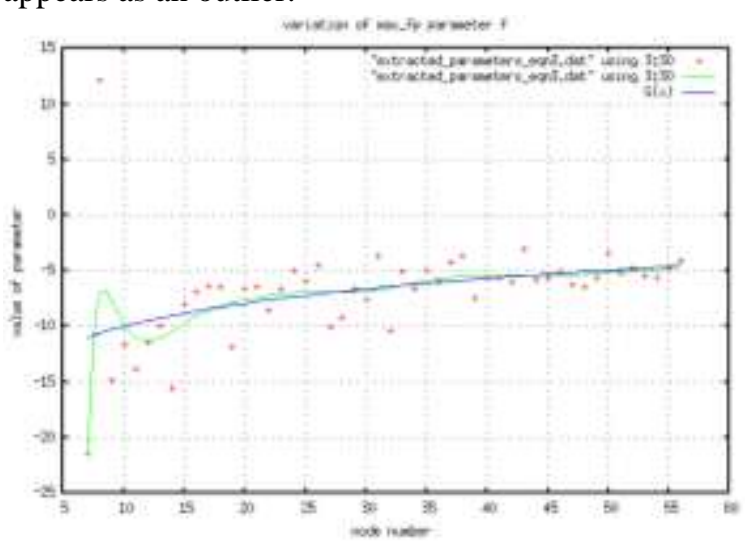

Figure 5: Max_FP parameter $f$

The applicable equation of trend is logarithmic:

$$
\begin{aligned}
& F(x)=a * \log ((b * x)+c)+d \\
& C h \_s q=18.0021
\end{aligned}
$$

The curve depicts good extendability feature.

The parameters for best fit are: $\mathrm{a}=3.50444, \mathrm{~b}=2.828$ $64, c=6.71468, d=-22.4841$

\subsection{Trend Analysis - Max FP parameter " $k$ ".}

Generally, a linear increasing tendency is depicted here. The plots, however, remain quite scattered.

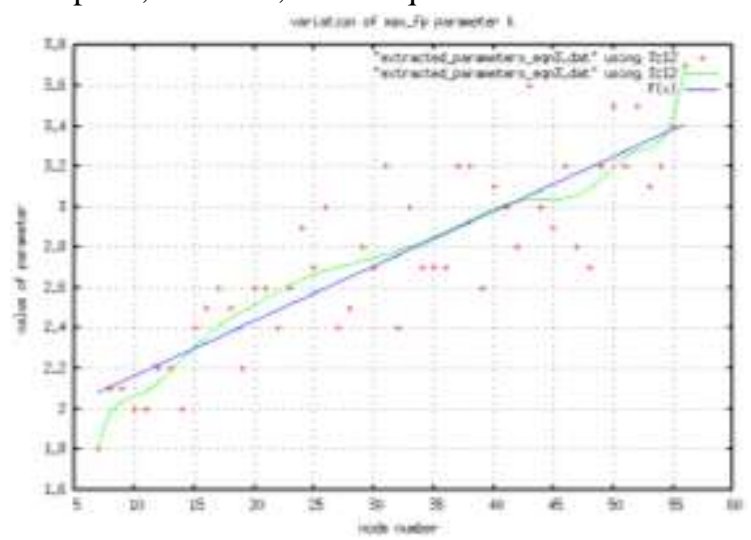

Figure 3: Max_FP parameter $k$

The applicable equation of trend has been linear:

$$
\begin{aligned}
\mathrm{F}(\mathrm{x})= & \mathrm{a} \star \mathrm{x}+\mathrm{b} \\
& \text { Ch_sq }=0.055
\end{aligned}
$$

The parameters for best fit are: $a=0.0270828, b=$ 1.89489

\section{Conclusion.}

This research activity was intended to and has accomplished the establishment of applicable models of trends of the parameters of equations for the metric Max_FP in a MANET topography of 300 x $300 \mathrm{~m}^{2}$. These models, put forward as equations of mathematical nature of varying complexity, will permit deeper study of MANETs for MAUC environments. Such development will entail the formulation of computational algorithms to be incorporated into simulators for more profound studies of MANETs. The experiment, whose output is reported in this paper, has been carried out in NS-2 over linux. The plottings and "fit" trials were conducted in gnuplot. Criteria for choosing best fit have been mostly value of least reduced chi-square and partly extendability offered at higher node number.

The reasonable assumptions put forward in a prior paper [24] are upheld in this paper also. Gnuplot is also assumed as convenient for this study.

Further work identified remain: formulating methods of predictability for metric Max_FP and its trend and reporting observations of certain critical values found.

\section{References}

[1] M. Kaleem GALAMALI, Assoc. Prof Nawaz MOHAMUDALLY, Towards Dependable Pervasive Systems-A Position and Vision Paper, CEET 2014

[2] M. Kaleem GALAMALI, Assoc. Prof Nawaz 
MOHAMUDALLY, Model of Energy Savings achievable with Location-aware Node-to-Node Transmission in UbiComp, CEET 2014

[3] M. Kaleem GALAMALI, Assoc. Prof Nawaz MOHAMUDALLY, Model of Energy Savings achievable with Location-aware Node-to-Node Transmission in UbiComp Using Location Refresh Intervals, CEET 2014

[4] M. Kaleem GALAMALI, Assoc. Prof Nawaz MOHAMUDALLY, Model of Energy Savings achievable with Location-aware Transmission in UbiComp Using Relays, CEET 2014

[5] M. Kaleem GALAMALI, Assoc. Prof Nawaz MOHAMUDALLY, Mathematical modeling of need of exact number of relays to ensure seamless mobility in mobile computing, CEET 2014

[6] M. Kaleem GALAMALI, Assoc. Prof Nawaz MOHAMUDALLY, Modelling of need for multiple relays for ensuring seamless mobility, CEET 2014

[7] M. Kaleem GALAMALI, Assoc. Prof Nawaz MOHAMUDALLY, Investigation of prominence of placements of relays in a ubicomp topography,

[8] M. Kaleem GALAMALI, Assoc. Prof Nawaz MOHAMUDALLY, Model of energy savings achievable with location-aware transmission in ubicomp using optimised number of relays.

[9] M. Kaleem GALAMALI, Assoc. Prof Nawaz MOHAMUDALLY, Investigation of Prominence of Placements of Optimised Number of Relays in a Ubicomp Topography using Location-Aware Transmission, CEET 2015

[10] M. Kaleem GALAMALI, Assoc. Prof Nawaz MOHAMUDALLY, Extending Node Battery Availability in Ubicomp with Location-Aware Transmission, CEET 2015.

[11] M. Kaleem GALAMALI, Assoc. Prof Nawaz MOHAMUDALLY, Extending Node Battery Availability in Ubicomp with Location-Aware Transmission using Location Refresh Intervals, CEET 2015.

[12] M. Kaleem GALAMALI, Assoc. Prof Nawaz MOHAMUDALLY, Extending Node Battery Availability in Ubicomp with Location-Aware Transmission using Uniformly Placed Relays, CEET 2015.

[13] M. Kaleem GALAMALI, Assoc. Prof Nawaz MOHAMUDALLY, Extending Node Battery Availability in Ubicomp with Location-Aware Transmission Using Optimally Placed Relays, CEET 2015.

[14] M. Kaleem GALAMALI, Assoc. Prof Nawaz MOHAMUDALLY, Model of Sender Node Energy Savings Achievable with Location-Aware MANET Transmission in Ubicomp. ACCN 2016

[15] M. Kaleem GALAMALI, Assoc. Prof Nawaz MOHAMUDALLY, Model of Overall Node Energy Savings Achievable with Location-Aware MANET Transmission in Ubicomp. ACCN 2016

[16] M. Kaleem GALAMALI, Assoc. Prof Nawaz MOHAMUDALLY, Model of Sender Node Extra Energy Savings Achievable in MANET Against Direct Node-toNode Transmission Using Location-Aware Transmission in Ubicomp. ACCN 2016

[17] M. Kaleem GALAMALI, Assoc. Prof Nawaz MOHAMUDALLY, Model of Overall Node Extra Energy Savings Achievable in MANET against Direct Node-toNode Transmission Using Location-Aware Transmission in Ubicomp. ACCN 2016

[18] M. Kaleem GALAMALI, Assoc Prof Nawaz MOHAMUDALLY, Model of Energy Consumption Ratio Achievable in MANET Using Location-Aware Transmission in Ubicomp. ACCN 2016

[19] M. Kaleem GALAMALI, Assoc. Prof Nawaz MOHAMUDALLY, Model of Minimum Energy Consumption Ratio Achievable in MANET Using LocationAware Transmission in Ubicomp. ACCN 2016

[20] M. Kaleem GALAMALI, Assoc. Prof Nawaz MOHAMUDALLY, Model of Maximum Energy Consumption Ratio Achievable in MANET Using LocationAware Transmission in Ubicomp. ACCN 2016

[21] M. Kaleem GALAMALI, Assoc. Prof Nawaz
MOHAMUDALLY, Model of Overall Energy Consumption Fairness Ratio Achievable in MANET Using LocationAware Transmission in Ubicomp. ACCN 2016

[22] M. Kaleem GALAMALI, Assoc. Prof Nawaz MOHAMUDALLY, Model of Overall Energy Consumption Fairness Proportion Achievable in MANET Using LocationAware Transmission for Ubicomp, CEET 2016

[23] M. Kaleem GALAMALI, Assoc. Prof Nawaz MOHAMUDALLY, Model of Minimum Fairness Proportion Achievable in MANET Using Location-Aware Transmission for Ubicomp, CEET 2016

[24] M. Kaleem GALAMALI, Assoc. Prof Nawaz MOHAMUDALLY, Model of Maximum Fairness Proportion Achievable in MANET Using Location-Aware Transmission for Ubicomp, CEET 2016

[25] M. Kaleem GALAMALI, Assoc. Prof Nawaz MOHAMUDALLY, Model of Sender Fairness Proportion Achievable in MANET Using Location-Aware Transmission for Ubicomp, CEET 2016

[26] M. Kaleem GALAMALI, Assoc. Prof Nawaz MOHAMUDALLY, Model of Distance Travelled by packets in MANETs using Location-Aware Transmission for Ubicomp, CEET 2016

[27] M. Kaleem GALAMALI, Assoc. Prof Nawaz MOHAMUDALLY, Model of Maximum CBR Distance Travelled by packets in MANETs using Location-Aware Transmission for Ubicomp, CEET 2016

[28] M. Kaleem GALAMALI, Assoc. Prof Nawaz MOHAMUDALLY, Model of Minimum CBR Distance Travelled by packets in MANETs using Location-Aware Transmission for Ubicomp, CEET 2016

[29] M. Kaleem GALAMALI, Assoc. Prof Nawaz MOHAMUDALLY, Model of Range CBR Distance Experienced by Transmissions in MANETs using LocationAware Transmission for Ubicomp, CEET 2016

[30] M. Kaleem GALAMALI, Assoc. Prof Nawaz MOHAMUDALLY, Trend Analyses of Parameters of Equations for Sender Node Energy Savings Achievable in ubicomp MANETs using Location-Aware Transmission, ACCN 2017.

[31] M. Kaleem GALAMALI, Assoc. Prof Nawaz MOHAMUDALLY, Trend Analyses of Parameters of Equations for Overall Node Energy Savings Achievable in ubicomp MANETs using Location-Aware Transmission, ACCN 2017.

[32] M. Kaleem GALAMALI, Assoc. Prof Nawaz MOHAMUDALLY, Trend Analyses of Parameters of Equations for Sender Node Extra Energy Savings Achievable in MANET against Direct Node-to-Node Location-Aware Transmission, ACCN 2017.

[33] M. Kaleem GALAMALI, Assoc. Prof Nawaz MOHAMUDALLY, Trend Analyses of Parameters of Equations for Overall Nodes Extra Energy Savings Achievable in MANET against Direct Node-to-Node Location-Aware Transmission, ACCN 2017.

[34] M. Kaleem GALAMALI, Assoc. Prof Nawaz MOHAMUDALLY, Trend Analyses of Parameters of Equations for Energy Consumption Ratio Achievable in Ubicomp MANET Using Location-Aware Transmission, ACCN 2017.

[35] M. Kaleem GALAMALI, Assoc. Prof Nawaz MOHAMUDALLY, Trend Analyses of Parameters of Equations for Minimum Energy Consumption Ratio Achievable in Ubicomp MANETs Using Location-Aware Transmission, ACCN 2017.

[36] M. Kaleem GALAMALI, Assoc. Prof Nawaz MOHAMUDALLY, Trend Analyses of Parameters of Equations for Maximum Energy Consumption Ratio Achievable in Ubicomp MANETs Using Location-Aware Transmission, ACCN 2017.

[37] M. Kaleem GALAMALI, Assoc. Prof Nawaz MOHAMUDALLY, Trend Analyses of Parameters of Equations for Overall Fairness Ratio Achievable in Ubicomp MANETs Using Location-Aware Transmission, ACCN 2017.

[38] M. Kaleem GALAMALI, Assoc. Prof Nawaz MOHAMUDALLY, Trend Analyses of Parameters of Equations for Energy Consumption Fairness Proportion Achievable in Ubicomp MANETs Using Location-Aware Transmission, CEET 
2017

[39] M. Kaleem GALAMALI, Assoc. Prof Nawaz MOHAMUDALLY, Trend Analyses of Parameters of Equations for Minimum Fairness Proportion Achievable in Ubicomp MANETs Using Location-Aware Transmission, , CEET 2017

[40] Markus Bylund and Zary Segall, Towards seamless mobility with personal servers, 2004.

[41] Masugi Inoue, Mikio Hasegawa, Nobuo Ryoki and Hiroyuki Morikawa, Context-Based Seamless Network and Application Control, 2004

[42] Xiang Song, Umakishore Ramachandran, MobiGo: A Middleware for Seamless Mobility, College of Computing Georgia Institute of Technology, Atlanta, GA, USA, August 2007

[43] Budzisz, Ferrús, R., Brunstrom A., Grinnemo, K, Fracchia, R., Galante, G., and Casadevall, F. Towards transport-layer mobility: Evolution of SCTP multihoming, March 2008

[44] Paul Dourish \& Genevieve Bell, Divining a digital future, 2011.

[45] Xiang Song, Seamless Mobility In Ubiquitous Computing Environments, PhD Thesis, Georgia Institute of Technology, August 2008

[46] Kevin O Mahony, Jian Liang, Kieran Delaney, User-Centric Personalization and Autonomous Reconfiguration Across Ubiquitous Computing Environments, NIMBUS Centre Cork Institute of Technology, Cork, Ireland, UBICOMM 2012

[47] Pablo Vidales, Seamless mobility in $4 \mathrm{G}$ systems, Technical Report, University of Cambridge, Computer Laboratory, Number 656, November 2005

[48] João Pedro Sousa and David Garlan, Aura: An Architectural Framework for User Mobility in Ubiquitous Computing Environments, School of Computer Science, Carnegie Mellon University, USA, August 2002

[49] Dennis Lupiana, Ciaran O’Driscoll, Fredrick Mtenzi, Defining Smart Space in the Context of Ubiquitous Computing, Dublin Institute of Technology, Ireland, Special Issue on ICIT 2009 Conference - Web and Agent Systems, 2009

[50] N.S.V.Shet1, Prof.K.Chandrasekaran2 and Prof. K.C.Shet3, WAP Based Seamless Roaming In Urban Environment with Wise Handoff Technique, International Journal of UbiComp (IJU), Vol.1, No.4, October 2010

[51] Yipeng $\mathrm{Yu}$ Dan He Weidong Hua Shijian Li Yu Qi Yueming Wang Gang Pan, FlyingBuddy2: A Braincontrolled Assistant for the Handicapped, Zhejiang University, UbiComp'12, September 5-8, 2012.

[52] Jing Su, James Scott, Pan Hui, Jon Crowcroft, Eyal de Lara Christophe Diot, Ashvin Goel, Meng How Lim, and Eben Upton, Haggle: Seamless Networking for Mobile Applications, 2007

[53] Rui Han, Moustafa M. Ghanem, Li Guo, Yike Guo*, Michelle Osmond, Enabling cost-aware and adaptive elasticity of multi-tier cloud applications, Future Generation Computer Systems, 2012

[54] Byrav Ramamurthy, K. K. Ramakrishnan, Rakesh K. Sinha, Cost and Reliability Considerations in Designing the NextGeneration IP over WDM Backbone Networks, 2012.

[55] Bhavish Aggarwal, Aditya Akella, Ashok Anand, Athula Balachandran, Pushkar Chitnis, Chitra Muthukrishnan, Ram Ramjee and George Varghese, EndRE: An End-System Redundancy Elimination Service for Enterprises, NSDI 2010, San Jose, CA

[56] Ashok Anand, Vyas Sekar and Aditya Akella, SmartRE: An Architecture for Coordinated Network-wide Redundancy Elimination, SIGCOMM 2009, Barcelona, Spain

[57] John Breeden II, "Smart-phone battery life could double without better batteries", Nov 14, 2012

[58] Andy Boxall, "When will your phone battery last as long as your kindle", December 5, 2012.

[59] Imielinski, T. and Navas, J.C. (1999). GPS-based geographic addressing, routing, and resource discovery. Comms. ACM, Vol. 42, No. 4, pp. 86-92.

[60] Hightower, J. and Borriello, G. (2001). Location Systems for Ubiquitous Computing. IEEE Computer, Vol. 34, No. 8, August, pp. 57-66.

[61] Harter, A., Hopper, A., Steggles, P., Ward, A. and Webster,
P. (2002). The Anatomy of a Context-Aware Application. Wireless Networks, Vol. 8, No. 2-3, Mar-May, pp. 187-197.

[62] Hightower, J., Brumitt, B. and Borriello, G. (2002). The Location Stack: A Layered Model for Location in Ubiquitous Computing. Proceedings of the 4th IEEE Workshop on Mobile Computing Systems \& Applications (WMCSA 2002), Callicoon, NY, USA, June, pp. 22-28.

[63] Graumann, D., Lara, W., Hightower, J. and Borriello, G. (2003). Real-world implementation of the Location Stack: The Universal Location Framework. Proceedings of the 5th IEEE Workshop on Mobile Computing Systems \& Applications (WMCSA 2003), Monterey, CA, USA, October, pp. $122-128$

[64] Ko, Y., \& Vaidya, N. H. (2000). Location-aided routing (LAR) in mobile ad hoc networks. Wireless Networks, 6(4), 307-321.

[65] Liao, W.-H., Tseng, Y.-C., \& Sheu, J.-P. (2001). GRID: a fully location-aware routing protocol for mobile ad hoc networks. Telecommunication Systems, 18(1), 37-60.

[66] Kuhn, F., Wattenhofer, R., Zhang, Y., \& Zollinger, A. (2003). Geometric ad-hoc routing: of theory and practice. In Proceedings of the ACM (PODC'03) (pp. 63-72).

[67] Jiang, X., \& Camp, T. (2002). Review of geocasting protocols for a mobile ad hoc network. In Proceedings of the Grace Hopper Celebration (GHC).

[68] Ko, Y. \& Vaidya, N. H. (1999). Geocasting in mobile ad hoc networks: location-based multicast algorithms. In Proceedings of the IEEE (WMCSA'99) (pp. 101).

[69] Mauve, M., Fuler, H., Widmer, J., \& Lang, T. (2003) Position-based multicast routing for mobile ad-hoc networks (Technical Report TR-03-004). Department of Computer Science, University of Mannheim.

[70] Xu, Y., Heidemann, J., \& Estrin, D. (2001). Geographyinformed energy conservation for adhoc routing. In Proceedings of the ACM/IEEE (MOBICOM'01) (pp. 70-84).

[71] Hu, Y.-C., Perrig, A., \& Johnson, D. (2003). Packet leashes: a defense against wormhole attacks in wireless ad hoc networks. In Proceedings of the INFOCOM' 03 (pp. 19761986).

[72] Patwari, N., Hero III, A. O., Perkins, M., Correal, N. S., \& O’Dea, R. J. (2003). Relative location estimation in wireless sensor networks. IEEE Transactions on Signal Processing, 51(8), 2137-2148.

[73] Baldauf, M., Dustdar, S., \& Rosenberg, F. (2007). A Survey on Context Aware Systems. International Journal of Ad Hoc and Ubiquitous Computing, Inderscience Publishers. forthcoming. Pre-print from: http://www.vitalab.tuwien.ac.at/ florian/papers/ijahuc2007.pdf

[74] Hong, D., Chiu, D.K.W., \& Shen, V.Y. (2005). Requirements elicitation for the design of context-aware applications in a ubiquitous environment. In Proceedings of ICEC'05 (pp. 590-596).

[75] Neeraj Tantubay, Dinesh Ratan Gautam and Mukesh Kumar Dhariwal, A Review of Power Conservation in Wireless Mobile Ad hoc Network (MANET)", International Journal of computer Science Issues, Vol 8, Issue 4, No 1, July 2011

[76] Wenrui Zhao, Mostafa Ammar and Ellen Zegura, "A Message Ferrying Approach for Data Delivery in Sparse Mobile Ad Hoc Networks", MobiHoc'04, May 24-26, 2004, Roppongi, Japan.

About Author (s)

Associate Professor Nawaz Mohamudally works at University of Technology, Mauritius (UTM) and has undertaken supervision of MPhil/PhD Students for many years. 
Proc. of the Seventh International Conference On Advances in Computing, Electronics and Electrical Technology - CEET 2017. Copyright () Institute of Research Engineers and Doctors. All rights reserved.

ISBN: 978-1-63248-126-9 doi: 10.15224/ 978-1-63248-126-9-13

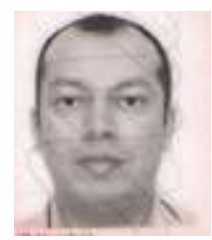

M. Kaleem Galamali is a part-time student (achieved M Phil Transfer on 28.10.2014, currently PhD student) at UTM under supervision of A.P. Nawaz Mohamudally. 